\title{
A Study on Humor Styles of Teacher Candidates
}

\author{
Bayram Așı1lıŏlu \\ ${ }^{1}$ Department of Educational Sciences, Ziya Gokalp Faculty of Education, Dicle University, Diyarbakir, Turkey \\ Correspondence: Bayram Aşılıoğlu, Department of Educational Sciences, Ziya Gokalp Faculty of Education, \\ Dicle University, Diyarbakir, Turkey. E-mail: bayramasilioglu@gmail.com
}

Received: October 10, 2020

doi:10.5539/ies.v14n3p138
Accepted: November 15, $2020 \quad$ Online Published: February 24, 2021

URL: https://doi.org/10.5539/ies.v14n3p138

\begin{abstract}
A teacher should have adaptive humor styles as well as knowledge, skills and attitudes about their profession. Humor styles affect many behaviors; from the relationships that teachers establish with their students to their characteristics. For this reason, this research was carried out to determine the humor styles of teacher candidates. 491 Teacher candidates have participated in this study, who were 3rd and 4th grade students in the faculty of education at 2 universities in Turkey. The researcher used the general survey model for the study. Data were collected using the Humor Styles Questionnaire (HSQ) developed by Martin et al. (2003). Findings showed that teacher candidates with the affiliative humor style had the highest average, those with the aggressive humor style had the lowest average. The averages of those with self-enhancing and self-defeating humor style were moderate. It was interpreted as positive that the average of those with self-enhancing humor style was high, as negative that the average of those with self-defeating humor style was moderate, and as positive the average of those with self-defeating humor style was low.
\end{abstract}

Keywords: humor style, sense of humor, teacher candidate, communication, well-being

\section{Introduction}

Since ancient times, people have laughed at some events they have experienced; they also try to understand the reason for laughter. The desire to understand the reasons for laughter has led to the emergence of three different theories about humor; superiority theory, relief theory and incongruity theory.

According to the superiority theory, humor is explained by behaviors related to superiority and humiliation. Philosophers such as Plato, Aristotle and Hobbes explained humor with a sense of superiority. Humor is a situation that emerges due to the sense of superiority an individual feels over other people and results in laughter (Morreall, 1997). According to the relief theory, most societies have taboos that prohibit the expression of impulses such as sexuality and violence. Therefore, people feel compelled to suppress behaviors such as violence and sexual urges. Repressed emotions cause an accumulation of psychic energy in them. If someone breaks taboos and articulates prohibited behaviors, people who correlate with these behaviors also release some of the psychic energy they have accumulated. The sense of relief created by this situation leads to humor (Newirth, 2006; Olin, 2016). Incongruity theory, on the other hand, tries to explain humor with the contradictions in life, there is a certain order in human life. The perception of disharmony that occurs when this order is disturbed creates a humorous situation and causes laughter (Attardo, 1994; Munde, 1997).

Until now, no theory has been developed that can fully explain human behaviors related to humor and laughter. Humor is a controversial concept; people still discuss on topics of what humor is or how humor should be. It is understood that people has not seen humor as a completely positive feature, in contrary to the current trend. Therefore, researchers interested in humor cannot agree on what humor and sense of humor are, so it is difficult to agree on a certain definition (Martin, Puhlik-Doris, Larsen, Gray, \& Weir, 2003; Yerlikaya, 2003).

Humor concept that has both cognitive and affective components in its structure mostly occurs in interpersonal relationships and is also considered as a personality trait. Therefore, humor has been considered as a versatile and comprehensive structure in most of the recent studies (Martin, 2000; Yerlikaya, 2003). Humor style is one of the dimensions in this structure. People's humor styles seem to affect their characteristics such as communication and problem-solving skills, self-esteem, psychological well-being, life satisfaction, social relationships, burnout, etc., according to findings of the studies on relationship between humor and human behavior (Cann, Zapata, \& Davis, 2009; Cayirdag \& Acar, 2010; Cheung \& Yue. 2012; Cheung \& Yue. 2013; Dyck \& Holtzman. 2013; Leist \& 
Müller, 2013; Martin et al., 2003; Recepoğlu, Kılınç, \& Çepni, O., 2011; Traş, Arslan, \& Mentiş-Taş, 2011; Tümkaya, 2007; Yerlikaya, 2003).

According to the principles Provin has brought to the humor literature, it is important to make eye contact and talk face-to-face in order to use humor effectively in the classroom. It is necessary to use humorous materials and to remove social barriers in order to create a comfortable and safe atmosphere in the classroom. Fulfilling these requirements facilitates memorization of new information, increases learning speed, improves problem solving skills, and decreases stress and test anxiety. This also ensures that students trust their teachers (Torok, McMorris, \& Lin, 2004; Haris, 2006). However, the fact that whether students react expectedly is closely related to the humor style that teacher uses in this process.

According to Martin et al. (2003), people have four different styles of humor. Out of these, those with affiliative and self-enhancing humor styles show adaptive behavior. Therefore, these two styles of humor are also called adaptive humor. Those who have aggressive and self-defeating humor styles show discordant behaviors. These two styles of humor are also expressed as maladaptive humor.

While teachers who have affiliative or self-enhancing humor style can create a positive atmosphere in the classroom, those who use aggressive and self-defeating humor style may cause students to experience disappointments and lose their self-esteem (Wanzer, Frymier, Wojtaszczyk, \& Smith, 2006). Humor can turn into implicit violence even in classroom, and students may experience feelings such as worthlessness, humiliation and degradedness. Researches show that these feelings create communication barriers between partners (Cann et al., 2009; Wanzer, Frymier, \& Irwin, 2010).

\subsection{Humor and Humor Styles}

In The Oxford English Dictionary (1986) Humor is defined as the quality of words, actions or writing which evokes emotions such as fun, strangeness, joy, joke, and humor (Simpson \& Weiner, 1989). Humor, more broadly, is the ability to perceive what is fun and funny or the ability to express it in written, verbal, and other contexts, or the ability to approach the subject with a joke or a playful imagination (Munde, 1997). It is one of the positive features that make easier for individuals to cope with difficult conditions and to adapt themselves to these conditions (Martin, et al., 2003). This ability develops mostly through interpersonal relationships. It is not only a personality trait, but also a tool helping individuals to perceive events from multiple perspectives, to be sensitive, to enrich their imagination, and to develop their empathic skills. Therefore, humor is a tool that colors life, entertains people, and facilitates social relationships (Kilic, 2016).

Humor affects many behaviors such as communication, well-being, anxiety and stress level of people. It has a multi-faceted structure that cannot be explained in one dimension, furthermore it has different styles. The humor styles that make up this structure can be examined in four categories: affiliative, self-enhancing, aggressive, and self-defeating. Humor styles are linked to self-regulation, self and well-being from different perspectives. People with affiliative humor style are expected to have predominantly positive emotions and moods such as extroversion, cheerfulness, self-confidence, relationship satisfaction (Lefcourt, 2001; Martin et al., 2003; Yerlikaya, 2003).

While individuals with self-enhancing humor style can often have fun with the incompatibilities of life, they can maintain their humorous perspective even in the face of stress or distress (Kuiper, Martin, \& Olinger, 1993; Martin et al., 2003; Yerlikaya, 2003). They receive positive and supportive answers from the people they interact with. Studies show that individuals with this humor style establish intimate and harmonious relationships (Dyck \& Holtzman, 2013). Self-enhancing humor can also contribute to subjective well-being of individuals by facilitating their social interactions, communication skills, and adaptation efforts (Özbay, Palancı, Kandemir, \& Çakır, 2012). Therefore, this humor style also reflects an understanding of using humor as an emotional regulation or coping mechanism (Martin, Kuiper, Olinger, \& Dans, 1993 cited in Martin et al., 2003). There is a negative correlation between this style of humor and negative feelings such as sadness and anxiety. So, we can say that it has a positive correlation with characteristics such as openness to experiences, self-esteem, and well-being (Yerlikaya, 2003). It is accepted that affiliative humor has a low association with aggressive and self-defeating humor.

Ziv (1988) states that humorous situations that develop spontaneously during the lesson will enrich the learning environment, however perfunctory humor will not be instructive. For this reason, Ziv recommends teachers to avoid humor styles that may lead to risky consequences. The self-enhancing humor is highly recommended because of its positive effects on well-being and quality of life (Leist \& Müller, 2013). Affiliative and self-enhancing humor styles foster social interaction. They create positive emotions in those who communicate. Therefore, these adaptive and unaggressive humor styles motivate students to learn, also entertain them (Banas, Dunbar, Rodriguez \& Liu, 2011), stimulate students' attention, reduce their stress and anxiety, create an environment for creative thinking, and allow them to perceive their teachers as sympathetic people, so strengthen 
the bond between students and teachers (Ivy, 2013; Karagül, 2018).

Aggressive humor style includes behaviors such as mocking, humiliating, degrading others. The negative effects (psychological and social consequences) of this style of humor are generally overlooked; it can have a negative effect on people of a certain gender or race. Manipulating the targeted person, group, gender, or race using funny expressions causes targeted people to feel humiliated. It is highly likely to harm and alienate them (Martin et al., 2003; Yerlikaya, 2003). The aggressive humor style is also based on the theory of superiority. According to Aristotle, humor is the combination of the pleasure due to the superiority we feel when we witness an unfortunate behavior of others, and the pain we feel when others laugh at us (Eastman, 1972; Sanders, 2001; Yerlikaya, 2003). According to Hobes, what makes us laugh is the sudden feeling of triumph that emerges as a result of comparing ourselves with the weaknesses of others, and it is based on the sudden perception of our dignity (Hobes, 1987 cited in Kuipers, 2008, p. 363).

Aggressive humor style is likely to harm and alienate others. This dimension of human is estimated to be in a positive correlation with neuroticism, especially hostility, anger, and aggression, and has a negative correlation with relationship satisfaction, intelligibility and conscientiousness (Martin et al., 2003). The use of negative and aggressive humor towards students creates an alarming and disturbing learning environment, reduces students' interest and participation in the course, and does not allow the instructor to evaluate the class (Banas et al., 2011). When teachers use aggressive humor more, their students believe less in their problem-solving ability and the possibility of finding solutions accordingly (Traş et al., 2011). Using aggressive humor style can satisfy superiority feeling of teachers, and also it can create humiliation feeling in their students. However, while the teacher is happy with the sense of superiority, students are more likely to experience emotions such as anger, anxiety, stress, helplessness, worthlessness, and loss of self-esteem.

Self-defeating humor involves trying to entertain others or have fun by doing or saying funny things at the expense of one's own unhappiness and feelings of humiliation. In this humor style, the individual aims to hide negative emotions or avoid dealing with problems constructively (Kubie, 1971 cited in Martin et al. 2003). Although those with this style of humor may seem humorous or funny (for example, "class clowns"), their use of humor underlies reasons such as emotional need, avoidance, and low self-esteem (Fabrizi \& Pollio, 1987; Martin et al., 2003; Yerlikaya, 2003; Teker et al., 2018). Hence, self-enhancing humor facilitates adaptation in human relationships, while self-defeating humor causes disruption of harmony (Dyck \& Holtzman, 2013).

Humor styles can affect human behavior and relationships with other people in many ways. For example, a negative correlation occurs between aggressive humor and creativity (especially fluency and originality) (Cayirdag \& Acar, 2010). Another study finding shows that human relationships are positively affected by affiliative and self-enhancing humor styles, and negatively affected by aggressive and self-defeating humor styles. Individuals with self-defeating humor style have higher depression and anxiety levels, and their life satisfaction levels are lower than individuals with affiliative or self-enhancing humor styles (Cheung \& Yue, 2013; Akdur \& Durak-Batıün, 2017).

Those who use self-defeating humor style (for example, those who hide their stress and unhappiness by joking and allow more mockery of themselves) create emotional distance in their relationships with others (Dyck \& Holtzman, 2013). Affiliative and self-enhancing humor styles not only increase life satisfaction, but also prevent the depressing mood and alleviate the negative effects of difficulties while maintaining life satisfaction (Cheung \& Yue, 2012).

Findings of another study, that was conducted to determine the relationship between humor styles, anxiety and self-sensitivity of teacher candidates, show that the levels of affiliative and self-enhancing humor styles have low-level negative relationships with self-judgment, isolation and over-identification, which are the negative sub-dimensions of the self-sensitivity scale. On the other hand, high levels of aggressive and self-defeating humor styles have low-level negative relationships with self-affection, awareness of sharing, and consciousness sub-dimensions of the self-compassion scale (Aydın, 2015).

\subsection{Purpose of the Study}

It depends on the humor style of the teacher to enhance the education process by using humor as a tool in education. For this reason, it would be useful to determine the correlation between humor styles and which humor styles teacher candidates tend to use before their service. We expect that the findings of this research provide feedback to teacher candidates to identify their needs in this field and to create a consistent sense of humor. For this purpose, answers to the following questions were sought:

- What humor styles do teacher candidates have? 
- What is the relationship between their humor styles?

\section{Methodology}

This research was carried out to determine the humor styles and the correlation between humor styles of teacher candidates studying at the faculty of education at 2 universities in Turkey.

\subsection{Research Model}

The researcher used the general survey model for this descriptive study. Survey studies aim to describe a past or present situation as it exists. Survey studies are based on collecting data to determine some characteristics of a group (Büyüköztürk, Çakmak, Akgün, Karadeniz, \& Demirel, 2012).

\subsection{Population and Sample}

The study was randomly determined among the population of 988 students studying at the $3^{\text {rd }}$ and $4^{\text {th }}$ year undergraduate students at Dicle University Ziya Gökalp Faculty of Education and Siirt University Faculty of Education in the spring semester of the 2018-2019 academic year, and consisted of 491 teacher candidates who participated voluntarily in the study.

\subsection{Data Collection Tool}

The data collection tool used in the study, the "Humor Styles Questionnaire" (HSQ), was developed by Martin et al. (2003).

\subsubsection{Humor Styles Questionnaire}

The original form of the scale was developed with data collected from participants between the ages of 14 and 87 , so HSQ is appropriate for both the young and the old (Martin et al. 2003). The scale was adapted to Turkish by Yerlikaya (2003). The original and Turkish-adapted forms of the scale have four independent sub-dimensions and 8 items in each sub-dimension. Table 1 shows Cronbach's Alpha values obtained from the original scale, the adapted form to Turkish, and this study.

Table 1. Cronbach Alpha internal consistency coefficients of the humor styles questionnaire according to its sub-dimensions

\begin{tabular}{ccccc}
\hline \multirow{2}{*}{ Sub-dimensions } & \multirow{2}{*}{ \# of items } & \multicolumn{3}{c}{ Cronbach Alpha Values } \\
\cline { 3 - 5 } & & HSQ Original Form & HSQ Turkish Form & Form used in this study \\
\hline Affiliative Humor & 8 & .80 & .78 & .73 \\
Self-enhancing Humor & 8 & .81 & .74 & .73 \\
Aggressive Humor & 8 & .77 & .69 & .57 \\
Self-defeating Humor & 8 & .80 & .67 & .63 \\
\hline
\end{tabular}

In this study, the reliability coefficients for the sub-dimensions of the scale were: .73 for the affiliative humor sub-dimension, .73 for the self-enhancing humor sub-dimension, .57 for the aggressive humor sub-dimension, and .63 for the self-defeating humor sub-dimension. Scales with a reliability coefficient between $0.5-0.8$ are considered to have moderate reliability (Salvucci, Walter, Conley, Fink, \& Saba, 1997).

\subsection{Data Analysis}

SPSS program was used in the statistical analysis of the data obtained in the study. The distribution of the data was examined before the analyses, and the skewness coefficients were examined for this purpose. The skewness coefficients were calculated as $-.23, .01,1.10$ and .10, for the sub-dimensions of affiliative, self-enhancing, aggressive and self-defeating humor styles respectively. The fact that the coefficients of skewness remain in the \pm 2 range reflects that there is no significant deviation from the normal distribution of the data, and indicates that parametric tests can be used (Bachman, 2004). After this determination, Pearson Moments Correlation analysis was performed to determine the relationships between the sub-dimensions of the scale. A correlation coefficient between 0.70 and 1.00 as an absolute value can be defined as high, between 0.70-0.30 as medium, and between 0.30 and 0.00 as a low level of correlation (Büyüköztürk, 2018, p. 32). The repeated measures ANOVA was used to examine whether there was a significant difference between the scores of the teacher candidates' humor styles in different sub-dimensions. If a significant difference was found as a result of repeated measurements ANOVA, the Post Hoc test was used for paired comparisons to determine the source of the difference, and then the Eta-squared value was examined to determine the size of the difference. If the calculated Eta-squared value is between .01 and .06, the difference is small; if Eta-squared value is between .06 and .14, the difference is moderate; and if it 
is .14 or higher, the difference is large (Cohen, 1988). Finally, while interpreting the scores of the participants from the sub-dimensions of the scale, the level of adoption of the related humor style is interpreted as high if 5.00 $<\bar{X} \leq 5.00$, moderate if $3.00<\bar{X} \leq 5.00$, low if $1.00 \leq \bar{X} \leq 3.00$, taking into account the use of seven-level grading in the scale.

\section{Findings}

The findings were analyzed from two perspectives: the descriptive analysis results of humor styles and the results related to the correlation between the sub-dimensions of humor styles.

Table 2. Descriptive analysis results for the humor styles questionnaire

\begin{tabular}{cccc}
\hline Sub-Dimensions & $\mathrm{N}$ & $\bar{X}$ & $\mathrm{Ss}$ \\
\hline Affiliative Humor & 491 & 5.02 & 1.11 \\
Self-enhancing Humor & 491 & 4.30 & 1.14 \\
Aggressive Humor & 491 & 2.82 & 1.06 \\
Self-defeating Humor & 491 & 3.49 & 1.02 \\
\hline
\end{tabular}

Table 2 shows that the highest average belongs to the affiliative humor sub-dimension $(\bar{X}=5.02)$, and the lowest average belongs to the aggressive humor $(\bar{X}=2.82)$ sub-dimension.

Table 3. Results regarding the correlation between sub-dimensions of humor styles

\begin{tabular}{|c|c|c|c|c|}
\hline & Affiliative Humor & Self-enhancing Humor & Aggressive Humor & Self-defeating Humor \\
\hline Affiliative Humor & 1 & & & \\
\hline Self-enhancing Humor & $.43^{* *}$ & 1 & & \\
\hline Aggressive Humor & $-.18^{* *}$ & $-.19^{* *}$ & 1 & \\
\hline Self-defeating Humor & $.10^{*}$ & $.15^{* *}$ & $.35^{* *}$ & 1 \\
\hline
\end{tabular}

The results of the correlation analysis show that there was a medium level correlation between self-enhancing humor style and affiliative humor style $(\mathrm{r}=.43 ; \mathrm{p}<.01)$, low level between aggressive humor style and affiliative humor style $(r=-.18 ; p<.01)$, low level between self-defeating humor style and affiliative humor style $(\mathrm{r}=.10$; $p<.05)$, low level between aggressive humor style and self-enhancing humor style $(r=-.19 ; p<.01)$, low level between self-enhancing humor style and self-defeating humor style $(\mathrm{r}=.15 ; \mathrm{p}<.01)$, and medium level correlation between aggressive humor style and self-defeating humor style.

Table 4. Multiple comparisons regarding the difference between sub-dimensions of the humor styles questionnaire

\begin{tabular}{ccccccc}
\hline & $F$ & Hypothesis sd & Error sd & P & Eta square & Source of difference \\
\hline Wilks' lambda & 304.77 & 3 & 488 & .00 & .65 & $1-2,3,4 ; 2-3,4 ; 3-4$ \\
\hline
\end{tabular}

Note. (1) Affiliative humor, (2) Self-enhancing humor, (3) Aggressive humor, (4) Self-defeating Humor

Table 4 shows that there is a significant difference between sub-dimensions $\left.\left[F_{(3-488)}=304.77, p<.01\right)\right]$. The eta-squared value (.65) shows that the difference is large. The averages for the sub-dimensions show that the highest value belongs to the Affiliative humor sub-dimension $(\bar{X}=5.02)$. The difference stems among all sub-dimensions.

\section{Discussion}

The highest average belongs to the affiliative humor sub-dimension of the scale among the humor styles of the teacher candidates. Since affiliative humor increases interpersonal harmony and attractiveness, it can be interpreted as a positive result for teacher candidates to have a high level of humor style in terms of fulfilling the requirements of the profession. Teacher candidates are also expected to internalize features such as extraversion, cheerfulness, self-confidence, sincerity, relationship satisfaction, positive mood (Martin et al., 2003), high life satisfaction, being able to get away from negative emotions and adapt to the environment (Cheung \& Yue, 2012) observed in people with affiliative humor. Thus, it becomes easier for them to adapt to the teaching profession they 
will undertake.

Teachers who make their students experience comforting feelings such as fun, trust, and well-being by using affiliative humor are perceived as sympathetic people by their students (Ivy, 2013; Karagül, 2018). This perception enables students to create constructive relationships with their friends. It increases their life satisfaction (Dyck \& Holtzman, 2013; Yue et al., 2014), and facilitates the realization of educational goals by making them open to communication (Jeder, 2014). For this reason, teacher candidates should be encouraged to participate in activities in order to use affiliative humor more.

The numerical value of the second sub-dimension of the scale shows that the teacher candidates have a moderate self-enhancing humor style. Teacher candidates who have this humor style can use humor to cope with life's difficulties, incompatibilities, stress, negative emotions and thoughts. They have a humorous perspective on life. They can often make fun of incompatibilities. They can maintain their humorous perspective even in the face of situations such as stress, distress, and anxiety (Kuiper et al., 1993). Their life satisfaction is high (Cheung \& Yue, 2012). They enjoy creating new experiences. They are extroverted and open to communication. In this respect, the result can be interpreted as positive for some of the participants. However, the fact that a significant portion of the teacher candidates do not have this humor style can be interpreted as a deficiency and indicates a need for education to be able to use this humor style.

There is a positive correlation between self-enhancing humor and well-being. The acceptance of the relationship in question lies behind its social approval (Dyck \& Holtzman, 2013). Because self-enhancing humor facilitates communication, social interaction and efforts to adapt, it can contribute to the well-being of individuals (Özbay et al., 2012). Therefore, the fact that teacher candidates have this humor style at a moderate level can be interpreted as they may have problems in dealing with problems using this humor style. This situation shows that teacher candidates need to improve their self-enhancing humor style. If their needs are met, their subjective well-being and life satisfaction can increase, and their communication with their students can become fun and satisfying. The use of humor as a strategy to improve education not only helps students engage with the subject, but also helps them learn by making the content easier to remember. Also, humor can serve different purposes of the teacher. For example, it facilitates teacher-student relationship, creates a positive classroom environment, and helps students relax by reducing their anxiety (Wanzer et al., 2006).

Aggressive humor is another humor style that teacher candidates have. Our study shows that the average calculated for the participants with this humor style was low. In this respect, it can be considered as a partially positive result.

Aggressive humor style is not generally adopted by the society because of the negative behaviors such as humiliating, degrading, mocking others that people use only to meet their own interests and desires. Aggressive humor can contain racist, sexist, or derogatory messages about the preferences of targeted people. Generally, the negative effects it will create on the targeted people are overlooked (Martin et al., 2003). There are studies showing that there is a negative correlation between aggressive humor and creativity (especially between fluency and originality) (Cayirdag \& Acar, 2010). Using aggressive humor weakens the positive interaction between teacher and students. It may affect students' self-esteem negatively. Being exposed to humorous attacks can cause students to feel worthless. This feeling hinders communication. As communication is impeded, the willingness to work cooperatively weakens and the possibility of cooperation to serve a common purpose gets more unlikely.

Our study showed that the teacher candidates had a moderate self-defeating humor style. This result can be evaluated as negative for the teacher candidates who have this feature. Individuals with this humor style use humor to avoid problems and hide the underlying facts about negative feelings (Teker et al., 2018). They try to cover up problems with humor. They prefer to avoid problems rather than try to solve them. For this reason, their depression and anxiety levels are higher than those with affiliative and self-enhancing humor styles (Akdur \& Durak-Batıün, 2017; Cheung \& Yue, 2013). In this case, their self-perception, self-confidence, self-esteem and life satisfaction are low.

The correlation between the humor styles of the teacher candidates shows that there is a moderate relationship between the adaptive (affiliative and self-enhancing) humor styles, and a moderate relationship between the maladaptive (aggressive and self-defeating) humor styles. On the other hand, there is a low level of correlation between adaptive humor styles and maladaptive (aggressive and self-defeating) humor styles. This result shows that teacher candidates who use a positive humor style prefer to use another positive humor style, while they are very unlikely to use negative humor styles. While teacher candidates who use one of the negative humor styles may prefer to use another negative humor style, it can be said that they are less likely to use a positive humor style.

As a result, the study shows that teacher candidates predominantly tend to use affiliative and self-enhancing humor style. Therefore, they can use humor as a tool that will facilitate their social relations and improve themselves. 
They can establish harmonious and constructive relationships with their students through humor. The study shows that those who have a self-enhancing humor style have high life satisfaction and can use humor as a tool to cope with problems. However, the study shows that the participants have a moderate self-enhancing humor style. Therefore, those who do not have this style of humor do not use humor to deal with anxiety, stress, negative emotions and thoughts. Teacher candidates who use humor for their aggressive purposes even if a little satisfy their own emotions, and they may cause students to experience feelings of worthlessness, anxiety, and guilt. They can be educated on the negative effects of this humor style. The average of teacher candidates, who tend to use self-defeating humor style, is also moderate. They use humor to hide problems instead of finding the real causes of negative emotions. They can be educated by creating appropriate environments to encounter positive humorous examples and to participate in activities.

\section{References}

Akdur, S., \& Durak-Batıgün, A. D. (2017). Mizah tarzları ile kişilik özellikleri, kişilerarası ilişki tarzları ve psikolojik sağlık arasındaki ilişkiler. Türk psikoloji yazıları, 20(39), 1-10.

Attardo, S. (1994). Linguistic theories of humor. Berlin/NewYork: Mouton de Gruyter.

Aydın, A. (2015). Identifying the relationship of teacher candidates' humor styles with anxiety and self-compassion levels. Eurasian Journal of Educational Research, 59, 1-16. https://doi.org/10.14689/ejer.2015.59.1

Bachman, L. F. (2004). Statistical analyses for language testing. Cambridge, UK: Cambridge University Press.

Banas, J. A., Dunbar, N., Rodriguez, D., \& Liu, S.-J. (2011). A review of humor in educational settings: Four decades of research. Communication Education, 60(1), 115-144. https://doi.org/10.1080/03634523.2010.496867

Büyüköztürk, Ş. (2018). Sosyal bilimler için veri analizi el kitabı: İstatistik, araştırma deseni SPSS uygulamaları ve yorum (24th ed.). Ankara: Pegem Akademi Yayınevi. https://doi.org/10.14527/9789756802748

Büyüköztürk, Ş., Çakmak, E. K., Akgün, Ö. E., Karadeniz, Ş., \& Demirel, F. (2012). Bilimsel Araştırma Yöntemleri (11th ed.). Ankara: Pegem Akademi Yayınevi.

Cann, A., Zapata, C. L., \& Davis, H. B. (2009). Positive and negative styles of humor in communication: Evidence for the importance of considering both styles. Communication Quarterly, 57, 452-468. https://doi.org/10.1080/01463370903313398

Cayirdag, N., \& Acar, S. (2010). Relationship between styles of humor and divergent thinking. Procedia-Social and Behavioural Sciences, 2(2), 3236-3240. https://doi.org/10.1016/j.sbspro.2010.03.494

Cheung, C. K., \& Yue, X. D. (2012). Sojourn students' humor styles as buffers to achieve resilience. International Journal of Intercultural Relations, 36(3), 353-364. https://doi.org/10.1016/j.ijintrel.2011.10.001

Cheung, C. K., \& Yue, X. D. (2013). Humor styles, optimism and their relationships with distress among undergraduates in Chinese cities. Humor: International Journal of Humor Research, 26(2), 351-370. https://doi.org/10.1515/humor-2013-0015

Cohen, J. (1988). Statistical power analysis for the behavioural sciences (2nd ed.). Hillsdale, NJ: Erlbaum.

Dyck, K. T. H., \& Holtzman, S. (2013). Understanding humor styles and well-being: The importance of social relationships and gender. Personality and Individual Differences, 55(1), 53-58. https://doi.org/10.1016/j.paid.2013.01.023

Eastman, M. (1972). The Sense of humor. New York: Octagon Books.

Fabrizi, M. S., \& Pollio, H. R. (1987). A naturalistic study of humorous activity in a third, seventh, and eleventh grade classroom. Merrill-Palmer Quarterly, 33, 107-128.

Harris, J. C. (2006). Should humor be a desired disposition for teacher candidates? Teacher Education Journal of South Carolina, 67-74.

Ivy, L. L. (2013). Using humor in classroom. Education Digest, 79(2), 54-57.

Jeder, D. (2014). Implications of using humor in the classroom. Procedia-Social and Behavioural Sciences, 180, 828-833. https://doi.org/10.1016/j.sbspro.2015.02.218

Karagül, A. (2018). İngilizce mizah metinlerinin 9. Sinıf ögrencilerinin İngilizce dersine yönelik tutumlarına etkisinin incelenmesi (Unpublished master's thesis). Dicle Üniversitesi Eğitim Bilimleri Enstitüsü, Türkiye. 
Kilic, Y. (2016). The views of Turkish teachers on the use of humor in secondary schools. Educational Research and Reviews, 11(9), 945-956. https://doi.org/10.5897/ERR2016.2785

Kuiper, N. A., Martin, R. A., \& Olinger, L. J. (1993). Coping humour, stress, and cognitive appraisals. Canadian Journal of Behavioral Science, 25, 81-96. https://doi.org/10.1037/h0078791

Kuipers, G. (2008). The sociology of humor, The primer of humor research (Ed: Victor Raskin). Berlin, NY: Mouton de Gruyter (pp. 361-398). https://doi.org/10.1515/9783110198492

Lefcourt, H. M. (2001). Humor: The psychology of living buoyantly. New York: Kluwer Academic Plenum Publishers. https://doi.org/10.1007/978-1-4615-4287-2

Leist, A. K., \& Müller, D. (2013). Humor types show different patterns of self-regulation, self-esteem, and well-being. Journal of Happiness Studies, 14, 551-569. https://doi.org/10.1007/s10902-012-9342-6

Martin, R. A. (2000). Humor and laughter. Encyclopaedia of Psychology (Ed: A. E. Kazdin), 4, 202-204. Washington, DC: American Psychological Association. https://doi.org/10.1037/10519-086

Martin, R. A., Puhlik-Doris, P., Larsen, G., Gray, J., \& Weir, K. (2003). Individual differences in uses of humor and their relation to psychological well-being: Development of the humor styles questionnaire. Journal of research in personality, 37, 48-75. https://doi.org/10.1016/S0092-6566(02)00534-2

Morreal, J. (1983). Gülmeyi ciddiye almak (Çev.: Kubilay Aysevener ve Şenay Soyer). İstanbul: İris Yayınları.

Munde, G. (1997). What are you laughing at? Differences in children's and adults' humorous book selections for children. Children's literature in education, 28(4), 219-233. https://doi.org/10.1023/A:1022423221342

Newirth, J. (2006). Jokes and their relation to the unconscious: Humor as a fundamental emotional experience. Psychoanalytic Dialogues, 16(5), 557-571.

Olin, L. (2016). Questions for a theory of humor. Philosophy Compass, 11(6), 338-350. https://doi.org/10.1111/phc3.12320

Özbay, Y., Palancı, M., Kandemir, M., \& Çakır, O. (2012). Üniversite öğrencilerinin öznel iyi oluşlarının duygusal düzenleme, mizah, sosyal öz-yeterlik ve başa çıkma davranışları ile yordanması. Türk Ĕgitim Bilimleri Dergisi, 10(2), 325-345.

Recepoğlu, E., Kılınç, A. Ç., \& Çepni, O. (2011). Examining teachers' motivation level according to school principals' humor styles. Educational Research and Reviews, 6(17), 928-934.

Salvucci, S., Walter, E., Conley, V., Fink, S., \& Saba, M. (1997). Measurement error studies at The National Centre for Education Statistics (NCES). Washington D.C.: U.S. Department of Education.

Sanders, B. (2001). Kahkahanın zaferi: Ylkıcı bir tarih olarak gülme (Çev. Kemal Atakay). İstanbul: Ayrıntı Yayınları

Teker, N., Çelikten, M., \& Halavuk, F. (2018). Eğitim yönetiminde mizah tarzı ve iş doyumu iliş̧isi. Uluslararası Toplum Araştırmaları Dergisi, 8(8), 521-546.

The Oxford English Dictionary. (1986). Oxford: Clarendon Press.

Torok, S. E., McMorris, R. F., \& Lin, W. (2004). Is humor an appropriate teaching tool? Perceptions of professors' teaching styles and use of humor. College Teaching, 52, 14-20. https://doi.org/10.3200/CTCH.52.1.14-20

Traş, Z., Arslan, C., \& Mentiş-Taş, A. (2011). Öğretmen adaylarında mizah tarzları, problem çözme ve benlik saygısının incelenmesi. Uluslararası Insan Bilimleri Dergisi, 8(2), 716-732.

Tümkaya, S. (2007). Burnout and humor relationship among university lecturers. Humor: International Journal of Humor Research, 20(1), 73-92. https://doi.org/10.1515/HUMOR.2007.004

Wanzer, M. B., Frymier, A. B., \& Irwin, J. (2010). An explanation of the relationship between instruction humor and student learning: Instructional humor processing theory. Communication Education, 59, 1-18. https://doi.org/10.1080/03634520903367238

Wanzer, M. B., Frymier, A. B., Wojtaszczyk, A. M., \& Smith, T. (2006). Appropriate and inappropriate uses of humor by instructors. Communication Education, 55, 178-196. https://doi.org/10.1080/03634520600566132

Yerlikaya, E. (2003). Mizah tarzları ölçeğinin uyarlama çalışması (Unpublished master's thesis). Çukurova Üniversitesi, Sosyal Bilimler Enstitüsü. Türkiye.

Yue, X. D., Liu, K. W., Jiang, F., \& Hiranandani, N. A. (2014). Humor styles, self-esteem, and subjective 
happiness. Psychological Reports: Mental \& Physical Health, 115, 517-525. https://doi.org/10.2466/07.02.PR0.115c18z6

Ziv, A. (1988). Teaching and learning with humor: Experiment and replications. Journal of Experimental Education, 6(1), 5-15. https://doi.org/10.1080/00220973.1988.10806492

\section{Copyrights}

Copyright for this article is retained by the author(s), with first publication rights granted to the journal.

This is an open-access article distributed under the terms and conditions of the Creative Commons Attribution license (http://creativecommons.org/licenses/by/4.0/). 